\title{
VALIDATION OF RAINFALL EROSIVITY ESTIMATORS FOR MAINLAND CHINA
}

\author{
Z. Zhu, B. Yu
}

\begin{abstract}
Methods are needed to estimate R-factor values and their seasonal distribution from daily rainfall totals in regions with little or no sub-daily rainfall intensity data. This study used calculated $R$-factor values for a 29-year period (1956-1984) for 22 locations in mainland China to evaluate two estimators of rainfall erosivity for large-scale application of the Universal Soil Loss Equation (USLE) or the Revised USLE (RUSLE), one for an R-factor estimated from mean annual precipitation and another for event erosivity from daily rainfall. This study shows that as a first approximation, the mean annual precipitation is non-linearly related to the $R$-factor, and that the relationship can be used to predict the $R$-factor for mainland China locations (Nash-Sutcliffe model efficiency $E_{c}=0.88, R M S E=28 \%$ of the mean). The nonlinear relationship for China is quite similar to those reported in other studies for Australia and the U.S. The study also shows that a daily rainfall erosivity model using average parameter values previously applied for Australia can satisfactorily estimate the seasonal variation in rainfall erosivity in addition to the R-factor for the mainland China locations $\left(E_{c}=0.90, R M S E=25 \%\right.$ of the mean). Once calibrated, model estimates of the R-factor and its monthly distribution from daily rainfall for the mainland China locations improved noticeably $\left(E_{c}=0.99, R M S E<10 \%\right.$ of the mean). The daily rainfall erosivity model and a gridded daily precipitation dataset (the China Gridded Daily Precipitation Product) with a $0.25^{\circ}(\sim 25 \mathrm{~km})$ resolution were then used to produce a concurrent daily rainfall erosivity map for the mainland China locations $\left(E_{c}=0.96, R M S E=\sim 23 \%\right.$ of the mean) for a 5-year period from April 2008 to March 2013. This study shows that: (1) mean annual precipitation can be used to estimate the R-factor for mainland China, Australia, and the U.S.; and (2) a calibrated daily rainfall erosivity model performed well in estimating the seasonal and interannual variations in rainfall erosivity, in addition to the $R$-factor, for large-scale erosion monitoring and assessments in China.
\end{abstract}

Keywords. China, Erosivity, Precipitation, R-factor, RUSLE.

T The Universal Soil Loss Equation (USLE) and more recently the Revised USLE (RUSLE) are widely used to predict long-term mean annual soil loss at the plot scale, and they have also been used for large-scale erosion assessment and inventory of natural resources (Wischmeier and Smith, 1978; Renard et al., 1997). One of the factors in the USLE/RUSLE is known as the rainfall-runoff erosivity $(R)$ factor, which quantifies the effect of climate on the average rate of erosion (Wischmeier and Smith, 1958). Renard et al. (1997) defined the $R$-factor as "the average annual total of the storm $E I$ values in a particular locality." The $E I$ (an abbreviation for energy times intensity) of a storm event is the product of the total storm energy $\left(E, \mathrm{MJ} \mathrm{ha}^{-1}\right)$ times the maximum 30 -min intensity $\left(I_{30}, \mathrm{~mm} \mathrm{~h}^{-1}\right)$ for the USLE/RUSLE (Renard et al., 1997). Hence, the SI unit of measurement for the $R$-factor is MJ.mm ha ${ }^{-1} \mathrm{~h}^{-1}$ year $^{-1}$ (Fos-

Submitted for review in October 2013 as manuscript number NRES 10451; approved for publication by the Natural Resources and Environmental Systems Community of ASABE in December 2014.

The authors are Zhongli Zhu, Assistant Professor, State Key Laboratory of Remote Sensing Science, School of Geography, Beijing Normal University, Beijing, China; Bofu Yu, Professor, School of Engineering, Griffith University, Nathan, Queensland, Australia Corresponding author: Bofu Yu, School of Engineering, Nathan Campus, Griffith University, 170 Kessels Road, QLD 4111, Australia; phone: +61-07-373-57486; e-mail: b.yu@griffith.edu.au. ter et al., 1981), while the customary English unit for the $R$-factor is hundreds $\mathrm{ft} \cdot$ tonf $\mathrm{acre}^{-1} \mathrm{~h}^{-1}$ year ${ }^{-1}$ (Renard et al., 1997).

To compute storm erosivity values and the $R$-factor, rainfall intensity data at time intervals of $30 \mathrm{~min}$ or less (preferably at a temporal scale of 1 to $10 \mathrm{~min}$ ) are required, as rainfall intensity is highly variable within a storm event. When this type of high-resolution rainfall intensity data is available, calculation of storm erosivities (and from them the $R$-factor) is trivial. The real challenge arises when the rainfall intensity record is short or incomplete, and both of these scenarios are quite common in practice. In addition, an erosivity predictor is most definitely needed when no high-resolution intensity data are available at the location of interest or when a large-scale application of the USLE/RUSLE framework for erosion prediction and assessment is planned. For this reason, many attempts have been made to develop and test alternative methods to estimate $R$-factor values from rainfall data that are much more readily available (e.g., Arnoldus, 1977; Richardson et al., 1983; Renard and Freimund, 1994; Yu and Rosewell, 1996a, 1996b; Angulo-Martínez and Beguería, 2009).

Renard and Freimund (1994) and $\mathrm{Yu}$ and Rosewell (1996a) developed simple relationships to predict the $R$-factor from mean annual rainfall. The similarity in terms of parameter values suggested the robustness of these relationships as predictors of the $R$-factor. To address the sea- 
sonal variation of rainfall erosivity, which is needed in the USLE/RUSLE to calculate the erosivity-weighted cover factor, predictive models to estimate daily, monthly, and seasonal erosivity values from daily rainfall amounts have been developed and widely tested (e.g., Yu and Rosewell, 1996b; Yu, 1998; Yu et al., 2001; Angulo-Martinez and Begueria, 2009). In particular, a model to estimate the sum of $E I_{30}$ values for month $j\left(\hat{E}_{j}\right)$ using daily rainfall amounts was developed in the form (Yu and Rosewell, 1996b):

$$
\hat{E}_{j}=\alpha[1+\eta \cos (2 \pi f j-\omega)] \sum_{d=1}^{N} R_{d}^{\beta} \text { when } R_{d}>R_{d o}
$$

where $R_{d}$ is the daily rainfall amount (mm), $R_{d o}$ is a threshold rainfall amount (mm), $N$ is the number of days in the month with a rainfall amount in excess of $R_{d o}$, and $\alpha, \beta, \eta$, and $\omega$ are model parameters described below. A sinusoidal function with a fundamental frequency $f=1 / 12$ is used to describe the seasonal variation of rainfall erosivity for a given amount of rain. For the Southern Hemisphere, the phase parameter $\omega$ is typically set to $\pi / 6$, indicating that for the same amount of rain, rainfall erosivity would be the highest in January (Yu and Rosewell, 1996b). The daily rainfall erosivity model was found particularly effective in various climate zones in Australia (Yu and Roswell, 1996b; $\mathrm{Yu}, 1998$ ), the equatorial region in Malaysia ( $\mathrm{Yu}$ et al. 2001), and elsewhere in the world (Angulo-Martínez and Beguería, 2009). Angulo-Martínez and Beguería (2009) showed that of five model formulations considered and tested, the one given in equation 1 performed best for a large number of locations in the northeastern part of Spain.

The daily rainfall erosivity model has three parameters ( $\alpha, \beta$, and $\eta$ ) that require calibration. The parameter $\alpha$ represents the level of rainfall erosivity for a given amount of rain in the month. Its absolute value is of paramount importance for unbiased estimates of the $R$-factor. The exponent $\beta$ is related to the nonlinear nature of the relationship between rainfall erosivity and rainfall amount. As rainfall amount increases, both the total storm energy and its peak intensity should increase. The increase in the product $E I_{30}$ is therefore greater than that in the rainfall amount; hence, the value of the exponent in equation 1 would be greater than 1 , generally in the range of 1.5 to $2(\mathrm{Yu}, 2003)$. The parameter $\eta$ is related to the seasonal effect on rainfall erosivity for a given amount of rain: the larger the $\eta$ value, the greater the $E I_{30}$ value in the warmer months than in the colder months for the same amount of rain. The parameter $\eta$ affects the seasonal distribution of rainfall erosivity but does not affect the overall level of erosivity. Given the model structure, the parameters are expected to have the following logical constraints: $\alpha>0, \beta>1$, and $0 \leq \eta<1$. It should be noted that the $\alpha$ and $\beta$ parameters are highly correlated in a log-linear relationship (Yu, 1998; $\mathrm{Yu}$ and Rosewell, 1996b).

For locations with sub-daily rainfall intensity data, the daily rainfall erosivity model can be calibrated to estimate model parameter values (Yu and Rosewell, 1996b; Yu, 1998; Yu et al., 2001). For locations without highresolution rainfall intensity data, parameter values for the model (eq. 1) need to be estimated to predict $E I_{30}$ values (and subsequently the $R$-factor) from daily rainfall amounts. Yu (1998) compiled parameter values from 74 locations in the temperate and tropical regions of Australia and recommended the following relationship for locations in Australia where only daily rainfall values are available (Yu, 1998):

$$
\alpha=0.395\left[1+0.098 \exp \left(3.26 R_{s} / R_{a}\right)\right]
$$

where $R_{a}$ is the mean annual rainfall (mm year ${ }^{-1}$ ), and $R_{s}$ is the mean summer rainfall (mm year ${ }^{-1}$ ) (November to April for the Southern Hemisphere). Yu (1998) also recommended using an average value of 0.79 for the parameter $\alpha$ where the empirical relationship (eq. 2) may not be applicable. Parameter values for $\beta$ and $\eta$ were set to 1.49 and 0.29 , respectively. When the threshold rainfall $\left(R_{o}\right)$ is set to $0 \mathrm{~mm}$, there is an increase in the $R$-factor, especially for areas of low precipitation (Yu, 1999), and the parameter $\alpha$ can be estimated from ( $\mathrm{Lu}$ and $\mathrm{Yu}, 2002)$ :

$$
\alpha=0.369\left[1+0.098 \exp \left(3.26 R_{s} / R_{a}\right)\right]
$$

Equations 1 and 2 or 3 allow prediction of monthly $E I_{30}$ values (and thus the $R$-factor) from daily rainfall amounts without calibration. For example, equations 1 and 3 , along with gridded daily rainfall data, were used to produce a rainfall erosivity map for a national land and water resources audit for Australia (Jeffrey et al., 2001; Lu and Yu, 2002).

A review of previous research in China showed that to estimate event erosivity values, or the $R$-factor, some subdaily rainfall characteristics were used in addition to precipitation amount for the northeastern part of China (Zhang et al., 1992), for the Loess Plateau (Wang and Jiao, 1996), and for the red soil region in southern China ( $\mathrm{Wu}, 1992$; Huang et al., 1992). In Chapter 3 of Jing et al. (2005), one of the most comprehensive studies of factors that affect soil erosion ever undertaken in China, it was recommended that mean annual precipitation and mean annual maximum $60 \mathrm{~min}$ and $24 \mathrm{~h}$ rainfall amounts be used to estimate the $R$ factor. There have been a few attempts in China to estimate event or monthly erosivity values from rainfall amounts only, mostly for a particular location, e.g., Wu (1994) for Anhui Province, Sun et al. (1990) for the southern part of Ningxia Province, Liu (1993) for the North Wei River, Zhou et al. (1995) for Fujian Province, and Liu et al. (2010) for Beijing. Zhang et al. (2002, 2003) developed an erosivity model using daily rainfall amounts for China; this model was also used to analyze long-term spatial and temporal variations in rainfall erosivity in the Chinese Loess Plateau region (Xin et al., 2011) and in the Yangtze River basin (Huang et al., 2012). These studies used a product of daily rainfall $(\mathrm{mm})$ and maximum $10 \mathrm{~min}$ rainfall intensity $\left(\mathrm{mm} \mathrm{h}^{-1}\right)$ for the day as a surrogate variable for $E I_{30}$. No estimators of rainfall erosivity using mean annual precipitation or daily rainfall amount have yet been developed and tested for mainland China.

The China Meteorological Administration (CMA) began to publish gridded daily precipitation for mainland China beginning in April 2008. This dataset, known as the China 
Gridded Daily Precipitation Product, is updated daily on the internet (http://cdc.cma.gov.cn/dataSetLogger.do?change Flag=dataLogger). With a validated daily rainfall erosivity model, it is now feasible to publish and update gridded rainfall erosivity values for China on a regular basis for nationwide erosion hazard monitoring.

The objectives of this study were to: (1) evaluate an estimator of the $R$-factor using the mean annual precipitation for 22 locations in mainland China, (2) evaluate a daily rainfall erosivity model to estimate the $R$-factor as well as its monthly distribution for the same locations, and (3) generate nearly real-time estimates of the spatial distribution of rainfall erosivity using the China Gridded Daily Precipitation Product. The results were evaluated using published $R$-factor data for the 22 locations in mainland China to provide an independent test of both the validity of the model formulation and the quality and usefulness of model parameter values. The results of the study provide estimators for $R$-factor values using precipitation amounts and an enabling technology for large-scale erosion monitoring for mainland China.

\section{Methods ANd Materials}

\section{STUDY AREA AND DATA SOURCE}

Jing et al. (2005) used rainfall intensity data collected with pluviometers for a period of 29 years (1956-1984) to calculate $E I_{30}$ and $R$-factor values for 22 locations in China (fig. 1 and table 1). They used the storm energy equation as a linear function of the logarithmic rainfall intensity, as recommended for the USLE (Wischmeier and Smith, 1978). A threshold of $10 \mathrm{~mm}$ was used to discard smaller rainfall events (Jiao, personal communication). The $R$-factor values were originally given in meter tonneforce $\cdot \mathrm{m} \mathrm{ha}^{-1} \mathrm{~h}^{-1}$ year $^{-1}$ (Jing et al., 2005), where tonne $\cdot$ force was given as weight, and these values were converted into the standard unit of measurement of MJ.mm ha ${ }^{-1} \mathrm{~h}^{-1}$ year $^{-1}$ by multiplying by a conversion factor of 9.81 based on the definition of tonne force as weight. Recorded daily precipitation data were obtained from the National Meteorological Information Center (NMIC) of the China Meteorological Administration (CMA). The daily data covered the same period from 1956-1984 for the 22 mainland China locations for which calculated $R$-factor values were available from Jing et al. (2005). The daily data for the 29 years were used in this study to evaluate the relationship between the mean annual rainfall and the $R$-factor for the mainland China locations, and for evaluating the daily rainfall erosivity model of Yu and Rosewell (1996b). The 22 locations were carefully selected to cover all major climatic zones (Jing et al., 2005) with mean annual precipitation varying from 206 $\mathrm{mm}$ year $^{-1}$ in the arid region in the northwest to $1844 \mathrm{~mm}$ year ${ }^{-1}$ in the south.

Gridded daily precipitation data at $0.25^{\circ}(\sim 25 \mathrm{~km})$ were

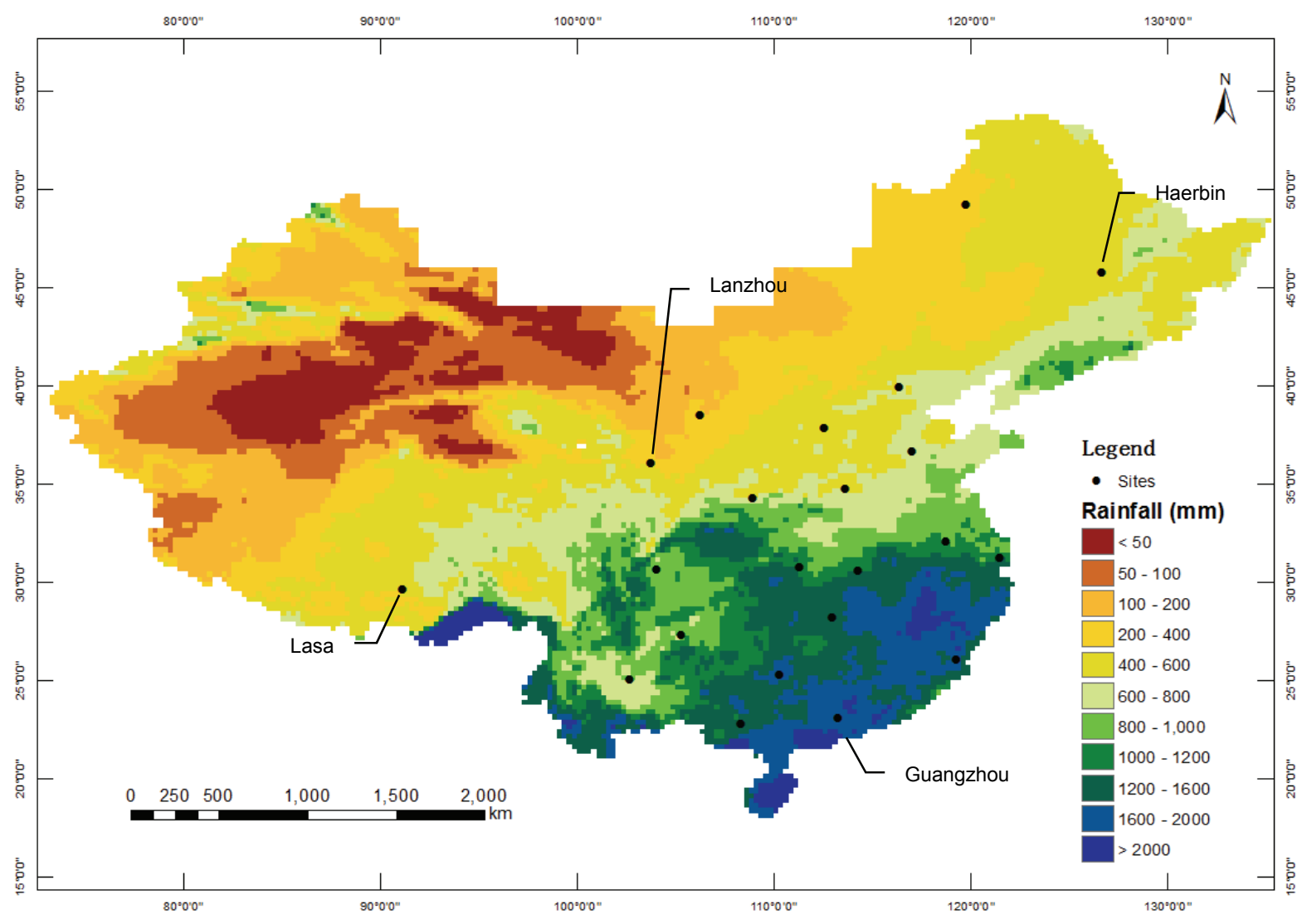

Figure 1. Spatial distribution of mean annual precipitation over a 5-year period (April 2008 to March 2013) calculated using the China Gridded Daily Precipitation Product. Shown also are 22 mainland China locations where $\boldsymbol{R}$-factor values were calculated from observed rainfall intensity data (Jing et al., 2005). The four indicated locations represent geographical extremes and were used to compare modeled and observed $E I_{30}$ values on annual and monthly bases (see figs. 7 and 8 ). 
Table 1. Location, mean annual precipitation (MAP), and $\boldsymbol{R}$-factor values of the 29 -year period from 1956 to 1984 for 22 locations in mainland China. The $R$-factor values were adapted from Jing et al. (2005). The MAP data for the period from April 2008 to March 2013 were based on the China Meteorological Administration (CMA) Gridded Daily Precipitation Product for the location grid cells. The adjusted R-factor values were calculated for the location grid cells using equation 11.

\begin{tabular}{|c|c|c|c|c|c|c|c|c|}
\hline $\begin{array}{c}\text { Station } \\
\text { No. }\end{array}$ & Location & $\begin{array}{l}\text { Latitude } \\
\text { (deg. N) }\end{array}$ & $\begin{array}{l}\text { Longitude } \\
\text { (deg. E) }\end{array}$ & $\begin{array}{c}\text { Elevation } \\
(\mathrm{m})\end{array}$ & $\begin{array}{c}\text { MAP } \\
(1956-1984) \\
\left(\mathrm{mm} \mathrm{year}^{-1}\right)\end{array}$ & $\begin{array}{c}R \text {-Factor } \\
\left(\mathrm{m} \cdot \mathrm{t} \cdot \mathrm{m} \mathrm{ha}^{-1}\right. \\
\left.\mathrm{h}^{-1} \text { year }^{-1}\right)\end{array}$ & $\begin{array}{c}\text { MAP } \\
\text { (April 2008 to } \\
\text { March 2013) } \\
\left(\text { mm year }^{-1} \text { ) }\right.\end{array}$ & $\begin{array}{c}\text { Adjusted } \\
R \text {-Factor } \\
\left(\mathrm{m} \cdot \mathrm{t} \cdot \mathrm{m} \mathrm{ha}^{-1}\right. \\
\left.\mathrm{h}^{-1} \text { year }^{-1}\right)\end{array}$ \\
\hline 54511 & Beijing & 39.48 & 116.28 & 31.3 & 609 & 336.3 & 603 & 330.1 \\
\hline 57707 & Bijie & 27.18 & 105.17 & 1510.6 & 937 & 272.9 & 822 & 217.5 \\
\hline 57679 & Changsha & 28.12 & 113.05 & 44.9 & 1415 & 426.4 & 1333 & 384.4 \\
\hline 56294 & Chengdu & 30.4 & 104.01 & 506.1 & 941 & 393.7 & 883 & 353.1 \\
\hline 58847 & Fuzhou & 26.05 & 119.17 & 84 & 1346 & 503.5 & 1508 & 612.4 \\
\hline 9287 & Guangzhou & 23.1 & 113.2 & 41 & 1701 & 1076 & 1674 & 1046.6 \\
\hline 57957 & Guilin & 25.19 & 110.18 & 164.4 & 1844 & 1094.2 & 1812 & 1061.4 \\
\hline 50953 & Haerbin & 45.45 & 126.46 & 142.3 & 527 & 147.2 & 517 & 142.1 \\
\hline 50527 & Hailaer & 49.13 & 119.45 & 610.2 & 346 & 55.5 & 323 & 49.1 \\
\hline 54823 & Jinan & 36.36 & 117.03 & 170.3 & 671 & 350.7 & 666 & 346.6 \\
\hline 56778 & Kunming & 25.00 & 102.39 & 1886.5 & 1013 & 286.9 & 716 & 158.0 \\
\hline 55591 & Lasa & 29.4 & 91.08 & 3648.9 & 424 & 32.5 & 378 & 26.6 \\
\hline 52889 & Lanzhou & 36.03 & 103.53 & 1517.2 & 316 & 44.3 & 303 & 41.3 \\
\hline 58238 & Nanjing & 32.00 & 118.48 & 7.1 & 1031 & 417.8 & 1054 & 433.5 \\
\hline 59431 & Nanning & 22.38 & 108.13 & 121.6 & 1304 & 751.2 & 1274 & 722.0 \\
\hline 58367 & Shanghai-longhua & 31.1 & 121.26 & 2.6 & 1115 & 356.9 & 1123 & 361.8 \\
\hline 53772 & Taiyuan & 37.47 & 112.33 & 778.3 & 457 & 110.2 & 428 & 98.3 \\
\hline 57494 & Wuhan & 30.37 & 114.08 & 23.1 & 1216 & 499.4 & 1205 & 492.2 \\
\hline 57036 & Xian & 34.18 & 108.56 & 397.5 & 583 & 84.3 & 632 & 97.0 \\
\hline 57461 & Yichang & 30.42 & 111.18 & 133.1 & 1161 & 433.9 & 1327 & 545.8 \\
\hline 53614 & Yinchuan & 38.29 & 106.13 & 1111.4 & 206 & 28.8 & 263 & 43.7 \\
\hline 57083 & Zhengzhou & 34.43 & 113.39 & 110.4 & 664 & 256.2 & 627 & 232.1 \\
\hline
\end{tabular}

obtained from the NMIC of CMA for a 5-year period from April 2008 to March 2013. The gridded data were prepared by NMIC with a real-time operational system of daily precipitation analysis over China using the original groundbased observations from 2419 stations or gauges. Daily observations were combined with long-term daily averages for spatial interpolation (Shen et al., 2010), and interpolated daily precipitation amounts were produced at $0.05^{\circ}(\sim 5 \mathrm{~km})$ resolution. The interpolated rainfall data were then resampled at $0.25^{\circ}$ resolution to generate the China Gridded Daily Precipitation Product for dissemination online (Shen et al., 2010). This product is updated daily (http://cdc.cma.gov.cn/dataSetLogger.do?changeFlag=data Logger) for registered users. For the 5 -year period considered, there were 34 missing days out of 1827 , or $1.9 \%$. No attempts were made to estimate rainfall amounts for missing days, and these days were not included in $R$-factor estimations.

For the 5-year period (April 2008 to March 2013) and each of the mainland China locations, daily values were extracted from the $0.25^{\circ}$ cell in which the site was located. The daily time series for the 22 separate cells were used to evaluate the calibrated daily rainfall erosivity model (eq. 1). Once evaluated, the gridded daily data were used to produce an erosivity map for the 5-year period for mainland China.

\section{MODEl PeRformance INDiCATORS}

Model performance, and hence its predictive ability, was quantified using the Nash-Sutcliffe coefficient of efficiency $E_{c}$ (Nash and Sutcliffe, 1970). $E_{c}$ is the fraction of total variation in the original data that can be explained by the model:

$$
E_{c}=1-\sum_{i=1}^{M}\left(y_{i}-\hat{y}_{i}\right)^{2} / \sum_{i=1}^{M}\left(y_{i}-\bar{y}\right)^{2}
$$

where $y_{i}$ and $\hat{y}_{i}$ are observed and modeled values, respectively, $\bar{y}$ is the average of observed values, and $M$ is the sample size. Essentially, $E_{c}$ is an indicator of how close the residuals of predicted versus observed values are to the $1: 1$ line. It is equivalent to the coefficient of determination $\left(\mathrm{R}^{2}\right)$ for linear regression models and can be considered a measure of model efficiency for many other types of models. This measure of model performance has been widely used to assess model performance in hydrology (e.g., Loague and Freeze, 1985) and soil sciences (e.g., Risse et al., 1993; King et al., 1996). The accuracy of these predictors was further assessed using a measure of the bias $(B, \%)$ and the root mean square error as percentage of the mean (RMSE\%), which are defined as:

$$
\begin{aligned}
B & =100\left(\frac{\sum \hat{y}_{i}}{\sum y_{i}}-1\right) \\
\mathrm{RMSE} \% & =\frac{100}{\bar{y}} \sqrt{\frac{1}{M} \sum\left(y_{i}-\hat{y}_{i}\right)^{2}}
\end{aligned}
$$

where the notations are the same as for equation $4 . B>0$ indicates overestimation, while $B<0$ indicates underestimation. RMSE\% provides a useful measure of the relative size of the error bars from the 1:1 line.

\section{R-FACTOR ESTIMATION FROM MEAN AnNual Precipitation}

$\mathrm{Yu}$ and Rosewell (1996a) presented a simple relationship to predict the $R$-factor from the mean annual precipita- 
tion $(P)$ :

$$
R=0.0438 P^{1.61}
$$

where $R$ is in MJ.mm ha ${ }^{-1} \mathrm{~h}^{-1}$ year $^{-1}$, and $P$ is in mm year ${ }^{-1}$. Equation 7 was developed using calculated $R$-factor values from 29 locations in southeastern Australia and is quite similar to the relationship developed by Renard and Freimund (1994) using calculated $R$-factor values from 132 locations in the U.S.:

$$
R=0.0483 P^{1.61}
$$

For this study, we sought a general relationship between the mean annual precipitation and the $R$-factor for the 22 mainland China locations in the form:

$$
R=a P^{b}
$$

as characterized by equations 7 and 8 .

\section{EROSIVITY ESTIMATION FROM DAILY RAINFALl AMOUNT}

To validate the daily rainfall erosivity model (eq. 1), daily rainfall data for the 22 mainland China locations were used to calculate annual totals of $E I_{30}$ values and $R$-factor values for the period 1956-1984. We compared the calculated $R$-factor values for the mainland China locations (Jing et al., 2005) with those estimated from daily rainfall data. In addition, we compared the time series of the annual sum of the $E I_{30}$ values as well as monthly fractions of the $R$-factor for four selected locations: Guangzhou (the most southerly location), Haerbin (the most easterly location), Lasa (the location with the highest elevation), and Lanzhou (the location with the second lowest $R$-factor value in the northwestern part of China) (fig. 1).

To establish baseline model performance, monthly sums of $E I_{30}$ values were initially predicted for the mainland China locations using average parameter values derived from 74 locations in Australia (table 3 in Yu, 1998) as follows: $\alpha=0.79, \beta=1.49$, and $\eta=0.29$. A rainfall threshold $\left(R_{d o}\right)$ of $10 \mathrm{~mm}$ was used, consistent with the original calculation of the $R$-factor (Jing et al., 2005; Jiao, personal communication). For the Northern Hemisphere, the value of the parameter $\omega$ was set to $7 \pi / 6$. This indicates that the rainfall erosivity would be highest in the month of July for a given amount of rainfall when the air temperature is generally the highest for the Northern Hemisphere. The predicted monthly sums of $E I_{30}$ values were then aggregated to predict annual sums of $E I_{30}$ and $R$-factor values for the mainland China locations.

In addition to using the default constant parameter values from Australia to assess model performance without calibration, equation 1 was calibrated for the mainland China locations using a simple global search method within a set range for each parameter. The ranges used were 0.04 to 3.0 for $\alpha, 1.0$ to 2.0 for $\beta$, and 0 to 1.0 for $\eta$. The objective function used was the sum of squared errors (SSE) between the observed and modeled $R$-factor values:

$$
\mathrm{SSE}=\sum_{k=1}^{M}\left(R_{k}-\hat{R}_{k}\right)^{2}
$$

where $R_{k}$ and $\hat{R}_{k}$ are observed and modeled $R$-factor values, respectively, for location $k$, and $M$ is the number of locations included for parameter calibration. The objective function was evaluated for all combinations of the $\alpha, \beta$, and $\eta$ parameters at a fixed increment of 0.04 for the period 19561984 for the mainland China locations. The calibrated parameter values were those associated with the minimum objective function value as a result of the evaluation procedure. It is worth noting that since the denominator in equation 4 for the Nash-Sutcliffe $E_{c}$ is constant for a given set of observed $R$-factor values, minimizing the objective function (eq. 10) is in effect equivalent to maximizing the $E_{c}$ in terms of $R$-factor values. In addition to calibrating the model (eq. 1) for the 22 mainland China locations as a whole, we also calibrated the model for the 19 locations in northern China and the three locations in southern China separately.

\section{ERosivity ESTIMATION USING GRIDDED Daily Precipitation Product}

To validate rainfall erosivity values using the gridded daily precipitation data for the 5-year (April 2008 to March 2013) period, we adjusted the calculated $R$-factor value for the 29-year (1956-1984) period, taking into account the difference in the mean annual precipitation between the two periods. Let $P$ be the 29-year mean annual precipitation, $P_{o}$ be the 5 -year mean annual precipitation, and $R$ be the $R$ factor for the 29-year period. The adjusted $R$-factor $\left(R_{o}\right)$ for the 5 -year period is given as:

$$
R_{o}=R\left(\frac{P_{o}}{P}\right)^{b}
$$

where the exponent $b$ was estimated from equation 9 .

To produce a contemporary rainfall erosivity map for the 5-year period, the China Gridded Daily Precipitation Product was used to produce two $R$-factor raster layers: an $\mathrm{N}$-layer with the parameter values for the northern part of China, and an S-layer for the southern part (table 2). For each grid cell, the average of the two estimates was used to determine whether the threshold of $6000 \mathrm{MJ} \cdot \mathrm{mm} \mathrm{ha}^{-1} \mathrm{~h}^{-1}$ year ${ }^{-1}$ was exceeded. If the $6000 \mathrm{MJ} \cdot \mathrm{mm} \mathrm{ha}^{-1} \mathrm{~h}^{-1}$ year $^{-1}$ threshold was exceeded, the value of that grid cell was replaced with the corresponding value from the S-layer; otherwise, the N-layer was used.

\section{RESULTS AND DISCUSSION \\ RELATIONSHIP BETWEEN MEAN ANNUAL PRECIPITATION AND $\boldsymbol{R}$-FACTOR}

Simple linear regression of the logs of the mean annual precipitation and the calculated $R$-factor values for the mainland China locations in China resulted in the following relationship (fig. 2):

$$
R=0.0241 P^{1.724}
$$


Table 2. Default and calibrated model parameter values and the corresponding model performance indicators for the daily erosivity model for mainland China. ${ }^{[a]}$

\begin{tabular}{|c|c|c|c|c|c|c|c|}
\hline & $\alpha$ & $\beta$ & $\eta$ & $M$ & $E_{c}$ & $B(\%)$ & RMSE\% \\
\hline Average parameter values for Australia & 0.79 & 1.49 & 0.29 & 22 & 0.90 & 1.5 & 25.3 \\
\hline $\begin{array}{l}R \text {-factor }<6000 \mathrm{MJ} \cdot \mathrm{mm} \mathrm{ha}^{-1} \mathrm{~h}^{-1} \text { year }^{-1} \\
\text { for the northern locations in China }\end{array}$ & 0.2 & 1.76 & 0.76 & 19 & 0.97 & 1.8 & 10.5 \\
\hline $\begin{array}{l}R \text {-factor }>6000 \mathrm{MJ} \cdot \mathrm{mm} \mathrm{ha}^{-1} \mathrm{~h}^{-1} \text { year }^{-1} \\
\text { for the southern locations in China }\end{array}$ & 0.68 & 1.58 & 0.38 & 3 & 0.98 & 0.1 & 2.1 \\
\hline Overall & - & - & - & 22 & 0.99 & 1.1 & 7.5 \\
\hline
\end{tabular}

a] $\alpha, \beta$, and $\eta$ are model parameters for equation $1 ; M$ is the number of locations; and $E_{c}, B$ (bias), and RMSE\% are model performance indicators defined by equations 4 to 6 .

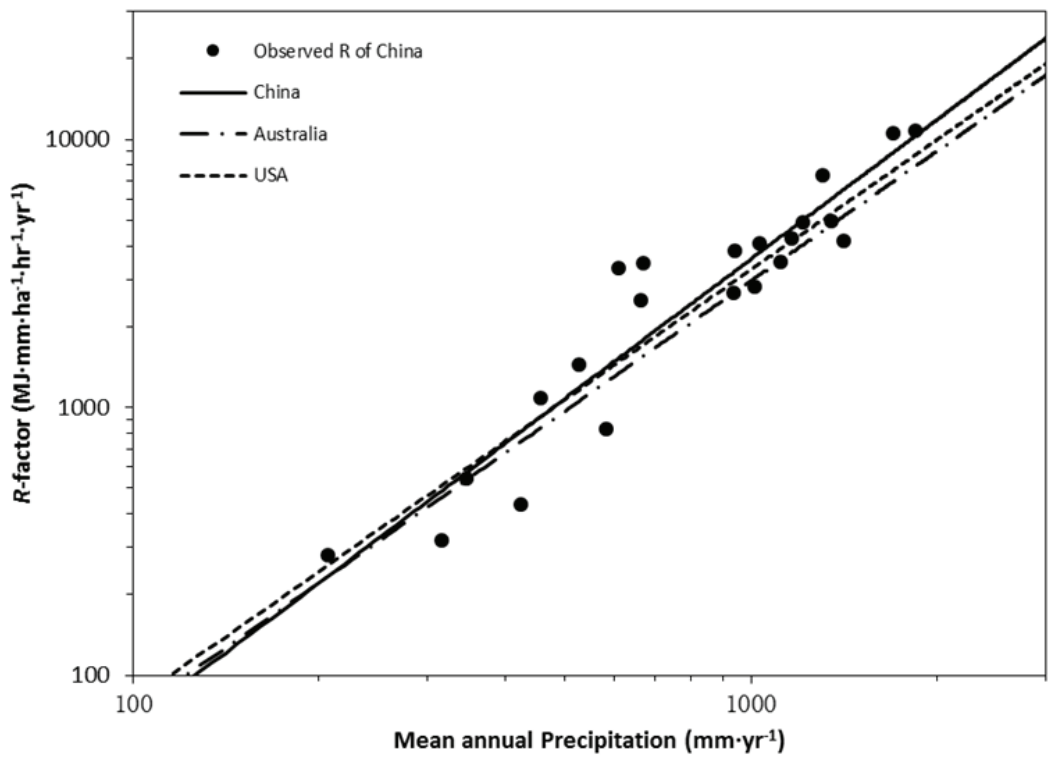

Figure 2. Relationship between mean annual precipitation and $\boldsymbol{R}$-factor for 22 mainland China locations in comparison with those in Australia (equation 7 in Yu and Rosewell, 1996a) and the U.S. (equation 8 in Renard and Freimund, 1994).

where $R$ is in $\mathrm{MJ} \cdot \mathrm{mm} \mathrm{ha}^{-1} \mathrm{~h}^{-1}$ year ${ }^{-1}$, and $P$ is in $\mathrm{mm} \mathrm{year}^{-1}$. The $\mathrm{r}^{2}$ value for the regression is 0.89 . It is well known that a bias can be introduced as a result of anti-log transformation, e.g., when sediment rating curves are used to estimate sediment discharge in rivers (Ferguson, 1986). A common solution is to use a correction factor to eliminate the bias; in this study, the correction factor was 1.063 using the smearing technique of Duan (1983). Other model performance indicators for the relationship given in equation 12 were $E_{c}=0.88, B=2.3 \%$, and $\mathrm{RMSE} \%=28 \%$. Regression equations for Australia (eq. 7 in $\mathrm{Yu}$ and Rosewell, 1996a) and the U.S. (eq. 8 in Renard and Freimund, 1994) are also shown in figure 2. All three equations are relatively similar, which suggests a universal nature of the relationship between the mean annual precipitation and the $R$-factor. The exponent between 1.61 and 1.72 indicates that the relationship is nonlinear and implies that for every $1 \%$ difference in the mean annual precipitation, a $1.6 \%$ to $1.7 \%$ difference in the $R$-factor value would be expected.

\section{VALIDATION OF DAILY RAINFALL EROSIVITY MODEl fOR MAINLAND CHINA}

Figure 3 shows the predicted and observed $R$-factor values for the 22 mainland China locations for the period 1956-1984 using the average parameter values derived from multiple locations in Australia. The predicted and observed values were in close agreement, with $E_{c}=0.90$,
$B=1.5 \%$, and $\mathrm{RMSE} \%=25 \%$. Further inspection of figure 3 shows that the model tended to systematically underestimate the $R$-factor when the $R$-factor values were greater than $6000 \mathrm{MJ} \cdot \mathrm{mm} \mathrm{ha}^{-1} \mathrm{~h}^{-1}$ year $^{-1}$ (Guangzhou, Nanning, and Guilin, all in the southern part of China) and overestimate the $R$-factor when the $R$-factor was less than this threshold (the 19 remaining locations).

Figure 4 shows the change in the Nash-Sutcliffe $E_{c}$ with

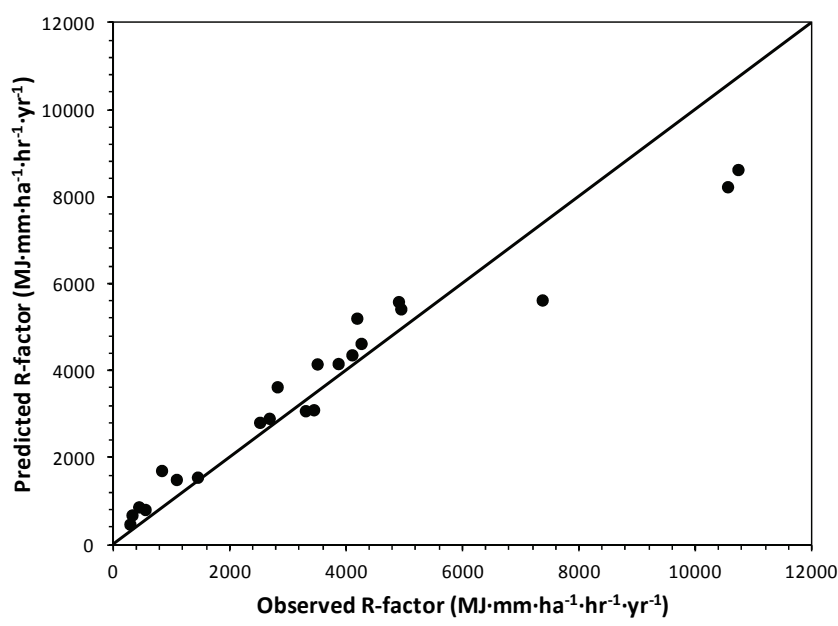

Figure 3. Comparison of the observed and predicted $\boldsymbol{R}$-factor values for 22 mainland China locations using equation 1 and average parameter values $(\alpha=0.79, \beta=1.49$, and $\eta=0.29)$ for 79 locations in Australia $(\mathrm{Yu}, 1998)$. 
$\eta$ when the $\alpha$ and $\beta$ values were fixed. It can be seen that the $E_{c}$ value increased from 0.6 to 0.974 and then decreased to 0.947 when the parameter $\eta$ was increased from 0 to 1 . A peak $E_{c}$ value of 0.974 was achieved when $\eta$ equaled 0.76 . Figure 4 also shows that the model performance was more sensitive to $\eta$ when $\eta$ was less than 0.5 , but $E_{c}$ was much less sensitive to $\eta$ around its optimal value of 0.76 . Figure 5 shows the variation in $E_{c}$ with respect to parameters $\alpha$ and $\beta$ when $\eta$ was fixed at 0.76 . In addition, figure 5 shows that for every $\alpha$ there would be an optimal $\beta$ value in terms of the $E_{c}$ value. If we plot the pairs of optimal $\alpha$ and $\beta$ values when one of them is fixed, we obtain a very good log-linear relationship between the two parameters. The relationship between $\alpha$ and $\beta$ for the 19 locations in northern China as a group can be described as a nearly perfect straight line (fig. 5):

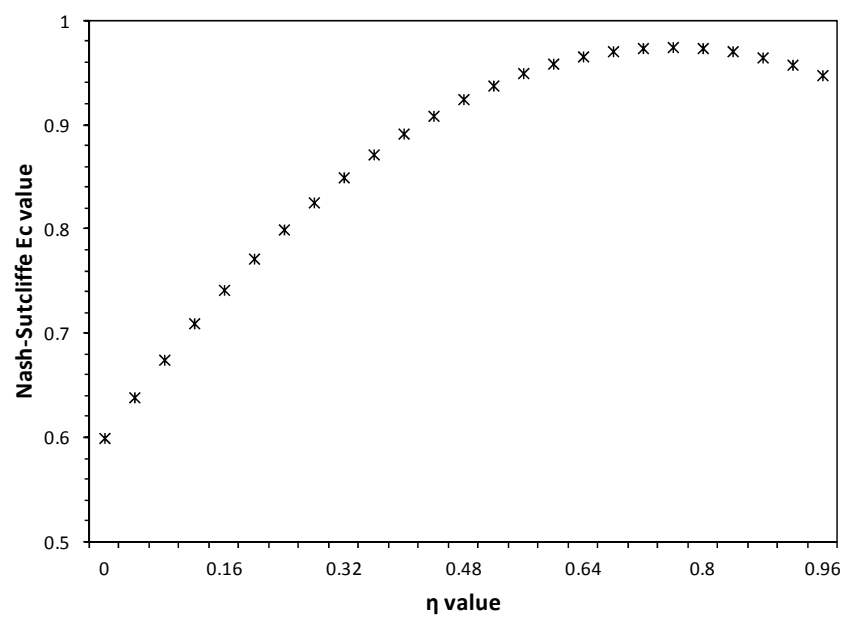

Figure 4. Changes in the Nash-Sutcliffe coefficient of efficiency $\left(E_{c}\right)$ with respect to parameter $\eta$ when parameters $\alpha$ and $\beta$ were fixed at 0.2 and 1.76, respectively. The $E_{c}$ value was computed in terms of $\boldsymbol{R}$-factor values for 22 mainland China locations using equation 1 and the fixed $\alpha$ and $\beta$ values.

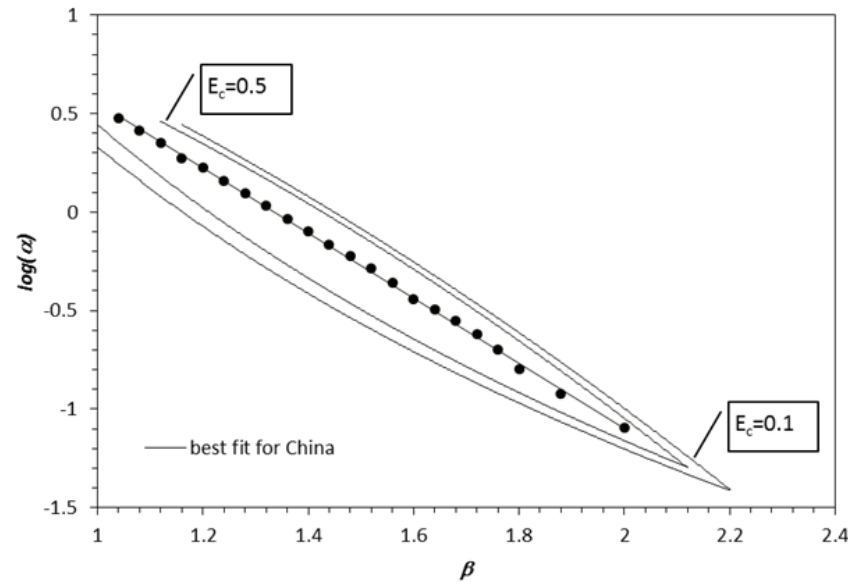

Figure 5. Contour lines of equal Nash-Sutcliffe $E_{c}$ values in relation to parameters $\alpha$ and $\beta$ with the parameter $\eta$ set to 0.76 . The $E_{c}$ value was computed using $R$-factor values for 22 mainland China locations. Data points are shown at a 0.04 interval for $\beta$ (1.04 to 2.0, excluding $1.84,1.92$, and 1.96) and corresponding $\alpha$ values where the highest $E_{c}$ value was reached. The solid line in the middle of the figure shows the best fit for the 22 data points.

$$
\log \alpha=2.23-1.67 \beta, r^{2}=0.998
$$

Equation 13 is nearly identical to the relationship between $\alpha$ and $\beta$ when optimized for 74 individual locations in Australia (Yu, 1998):

$$
\log \alpha=2.32-1.64 \beta, r^{2}=0.90
$$

The similar relationship between the $\alpha$ and $\beta$ parameter values, whether calibrated for individual locations or for a group of locations, suggests an underlying reason as to why the default parameter values $(\alpha=0.79, \beta=1.49$, and $\eta=$ $0.29)$ for Australia provided satisfactory estimates of the $R$-factor for the 22 locations in mainland China.

The calibrated parameter values and model performance for each group and the overall model performance for the mainland China locations are presented in table 2. A comparison of the modeled and observed $R$-factor values is shown in figure 6 . This figure and table 2 show that with separate sets of parameter values for the two groups, model performance improved markedly, with $E_{c}=0.99$ and RMSE $\%=7.5 \%$ (table 2). Table 2 also shows that the optimized value for the exponent $\beta$ was higher for the 19 locations in the northern part of China than for the three southern locations. This is broadly consistent with previous observations that $\beta$ tends to be higher at higher latitudes (Yu, 1998, 2003). The parameter $\alpha$ is strongly correlated with the exponent $\beta$ (Yu, 1998). Based on the log-linear relationship between the $\alpha$ and $\beta$ parameters in Australia and for the group of 19 locations in mainland China (eq. 13), a difference in $\beta$ of 0.1 unit (table 2) is expected to result in a difference in $\alpha$ by a factor of 0.69 (Yu, 1998). Thus, given a value of 0.68 when $R>6000 \mathrm{MJ} \cdot \mathrm{mm} \mathrm{ha}^{-1} \mathrm{~h}^{-1}$ year $^{-1}$ (table 2 ), the expected $\alpha$ value would be about 0.47 for locations with lower $R$-factor values. The actual calibrated value for $\alpha$ was 0.32 when $R<6000 \mathrm{MJ} \cdot \mathrm{mm} \mathrm{ha}^{-1} \mathrm{~h}^{-1}$ year $^{-1}$ (table 2). The difference in terms of the $\alpha$ value is a result of the differing $\beta$ value as well as the underlying physical processes, i.e., as the latitude increases, rainfall erosivity would decrease for a given amount of rain (other factors being the same), resulting in a smaller value for $\alpha$ than expected.

The time series of annual sum of $E I_{30}$ values for the Guangzhou, Haerbin, Lasa, and Lanshou locations, as described above, is shown in figure 7 . The estimated annual sum of $E I_{30}$ values compared very well $\left(E_{c}=0.72, B=\right.$ $1.06 \%$ ) with the observed annual sum of $E I_{30}$ values for Guangzhou in southern China, where the rainfall erosivity is high. For Haerbin $\left(E_{c}=0.57, B=-0.4 \%\right)$ in northeastern China, overestimation tended to occur in years of low erosivity and underestimation in years of high erosivity. For locations where the level of erosivity is low, such as Lanzhou $\left(E_{c}=0.15, B=87 \%\right)$ and Lasa $\left(E_{c}=-1.6, B=75 \%\right)$, the agreement between observed and estimated annual totals of $E I_{30}$ values was worse because of overestimation for most of the years. The overestimation for locations of low $R$-factor, while less prominent in figure 6 , is quite evident in figure 7, where annual totals are presented for individual locations. This difference may result from the relative low 


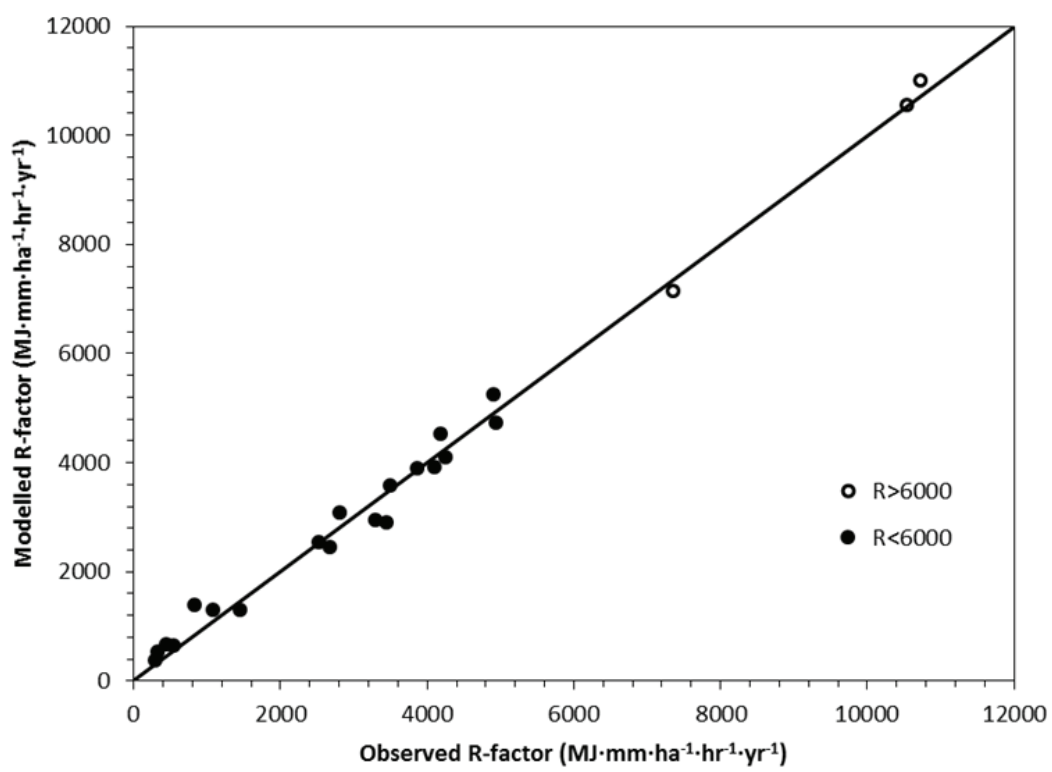

Figure 6. Comparison of observed and modeled $R$-factor values using calibrated parameter values for 22 mainland China locations, where $R$-factor values $>6000 \mathrm{MJ} \cdot \mathrm{mm} \mathrm{ha}^{-1} \mathrm{~h}^{-1}$ year ${ }^{-1}$ are for the southern locations (Guangzhou, Guilin, and Nanning) and $R$-factor values $<6000 \mathrm{MJ} \cdot \mathrm{mm} \mathrm{ha}^{-1} \mathrm{~h}^{-1} \mathrm{year}^{-1}$ are for the other (northern) locations.
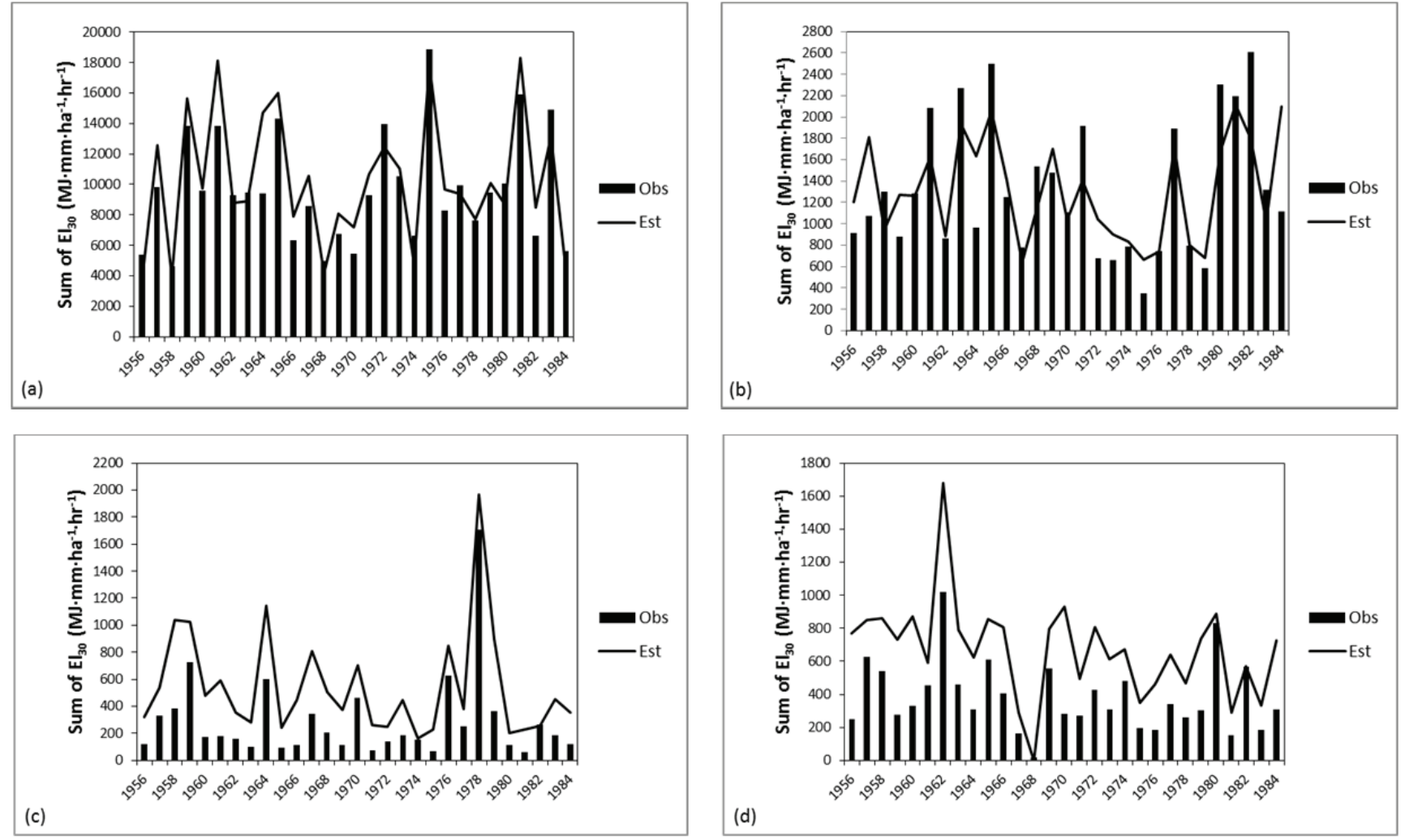

Figure 7. Time series of observed and estimated annual sums of event $E I_{30}$ values for four selected locations in China: (a) Guangzhou, (b) Haerbin, (c) Lanzhou, and (d) Lasa.

mean annual precipitation, i.e., $316 \mathrm{~mm}$ year $^{-1}$ for Lanzhou and $424 \mathrm{~mm}_{\text {year }}{ }^{-1}$ for Lasa. When calculating the eventbased annual total of $E I_{30}$ values with rainfall intensity data, a $10 \mathrm{~mm}$ total rainfall depth threshold was used for individual storm events, and all storms with total rainfall less than this depth were discarded. On the other hand, the estimated annual total $E I_{30}$ value was based on daily rainfall, and only daily rainfall totals less than $10 \mathrm{~mm}$ were discarded. This difference may have affected $E I_{30}$ estimation for the arid or semi-arid areas, such as the northwestern part of China, but probably had little impact in more humid regions in southern China. Yu (1999) showed that the effect of this rainfall threshold on the calculated $R$-factor values increased dramatically when the mean annual precipitation fell below about $500 \mathrm{~mm}_{\text {year }}{ }^{-1}$. Figure 8 shows the monthly distribution of rainfall erosivity for the four selected locations. It 
can be seen that the agreement was excellent for all four locations irrespective of the location and the mean annual precipitation. The mean absolute discrepancy between estimated and observed monthly distribution varied from $0.3 \%$ (Lasa) to $1.5 \%$ (Lanzhou).

\section{VALIDATION AND APPLICATION USING GRIDDED Daily Rainfall Product for Mainland China}

Figure 9 shows a comparison between the observed and predicted $R$-factor using the China Gridded Daily Precipitation Product for the 5-year period from April 2008 to March 2013. Note that the $R$-factor values were adjusted using equation 11 and a $b$ value of 1.724 from equation 12 to take into account the variation in the mean annual precipitation between the 5-year period and the 29-year period for the observed $R$-factor values. The ratio of the 5 -year mean to the 29-year mean varied from 0.71 to 1.27 for the 22 mainland China locations, resulting in adjustment by a factor varying from 0.55 to 1.52 (eq. 11). The predicted $R$ factor values for the mainland China locations were based on equation 1 and group-specific parameter values (table 2) without any further modification. Figure 9 illustrates that the predicted and observed $R$-factor values, adjusted for variations in the mean annual precipitation between the different periods, were in a good agreement for the locations considered. The error bars in figure 9 represent one standard error of the predicted and observed $R$-factor values. The size of the error bars is $13.6 \%$ on average for the mainland China locations. Due to the short time period (5 years) of the predicted $R$-factor, its standard error of the mean is larger by about $6.5 \%$ on average than that of the
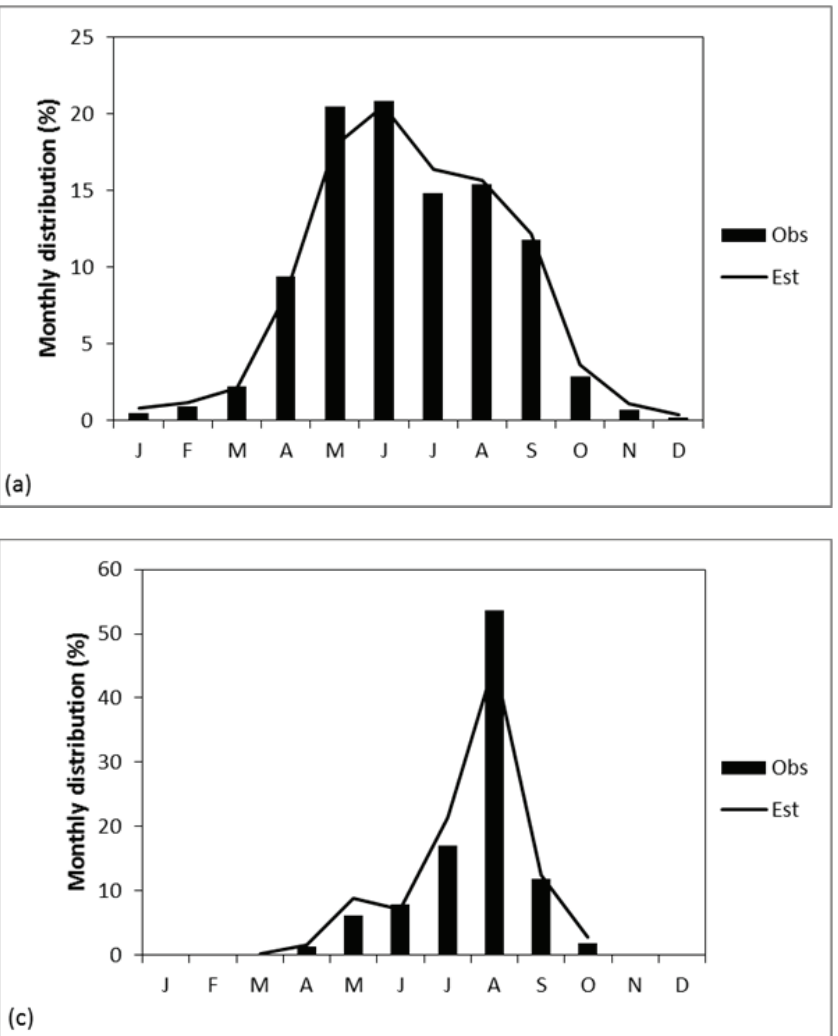

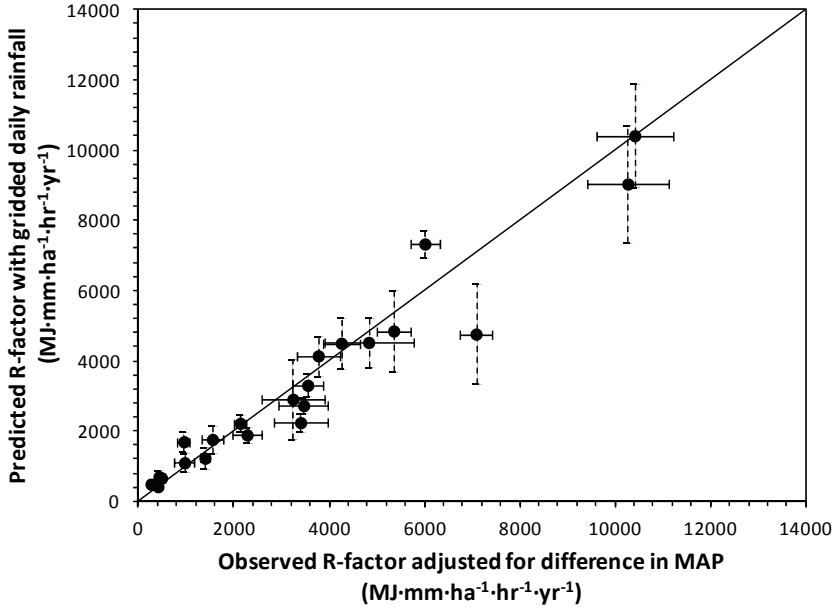

Figure 9. Comparison of observed $\boldsymbol{R}$-factor values adjusted due to variations in the mean annual precipitation (MAP) and those predicted using the China Gridded Daily Precipitation Product for 22 mainland China locations over a 5-year period (April 2008 to March 2013).

observed $R$-factor for the 29-year period. Model performance $\left(E_{c}=0.96, B=10.3 \%\right.$, and $\left.\mathrm{RMSE} \%=23 \%\right)$ quantitatively shows that the daily rainfall erosivity model can be applied to estimate the $R$-factor using the China Gridded Daily Precipitation Product. In summary, the 5-year rainfall erosivity predicted using the China Gridded Daily Precipitation Product does not have a large bias, and the uncertainty (as measured by the error bars) is not greatly different from observed rainfall erosivity for the mainland China locations.
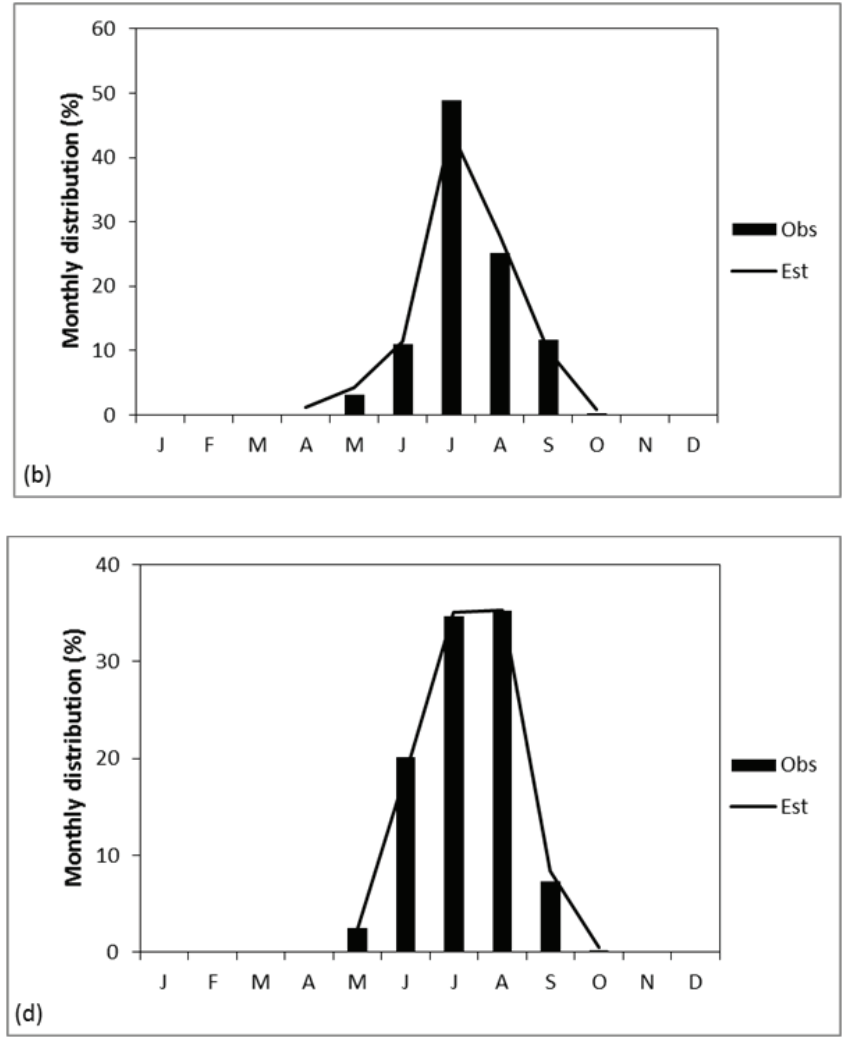

Figure 8. Comparison of observed and estimated monthly distribution of the $R$-factor for four selected locations in China: (a) Guangzhou, (b) Haerbin, (c) Lanzhou, and (d) Lasa. 
Figure 10 shows the spatial distribution of the predicted $R$-factor over the 5-year period using the China Gridded Daily Precipitation Product. The spatial distribution of rainfall erosivity is broadly similar to that of rainfall distribution for mainland China for the period (fig. 10 vs. fig. 1), with a predominant northwest to southeast gradient of increasing rainfall erosivity. The largest $R$-factor values were found along the south slope of the Himalayan Mountains, Hainan Province and Guangdong Province, and the lowest mainly located in the desert area of the Xinjiang Uygur Autonomous Region.

\section{SUMMARY AND CONCLUSIONS}

In regions where little or no sub-daily rainfall intensity data are available, there remains a need to estimate the USLE/RUSLE $R$-factor value and its seasonal distribution from data that are readily and routinely obtainable. This study shows that as a first approximation, mean annual precipitation can be used to predict the $R$-factor with reasonable accuracy for mainland China, Australia, and the U.S. To describe the seasonal variation in rainfall erosivity, mean annual precipitation is not adequate. This study also illustrates that a daily rainfall erosivity model (eq. 1) can be used to predict daily and monthly total of $E I_{30}$ values (and subsequently the $R$-factor and its seasonal distribution) once model parameter values are estimated through model calibration. It was reassuring to note that even average parameter values for Australia could be used to predict the $R$ - factor and its monthly distribution for mainland China locations reasonably well. The daily erosivity model is useful and the results are robust because the model structure captures four fundamental aspects of the relationship between rainfall and the product of storm energy and peak rainfall intensity. The parameters $\beta$ and $R_{d o}$ are related to the nonlinear relationship between rainfall erosivity/amount and threshold rainfall, respectively. Through the sinusoid function, the parameter $\eta$ captures the effect of seasonality, i.e., rainfall erosivity is higher for the same amount of rainfall in warmer months than in cooler months. The parameter $\alpha$ is critical because it determines whether the predicted $R$-factor values are biased or not. For a given $\beta$ value, the corresponding $\alpha$ value does not vary a great deal, hence the reliable prediction of the $R$-factor using even average $\alpha$ values.

In conclusion, the relationship between the mean annual precipitation and the $R$-factor is quite similar and robust for mainland China, Australia, and the U.S., implying that the mean annual precipitation could be used to estimate the $R$-factor reliably. The daily rainfall erosivity model was shown to perform well in estimating the seasonal and interannual variations in the rainfall erosivity for mainland China. Once calibrated, the daily rainfall erosivity model can be used to map rainfall erosivity using grid-based daily precipitation data for large-scale soil erosion monitoring and assessment. This and previous studies seem to indicate that the formulation and structure of the daily erosivity model is nearly optimal. Implementation of the model as an

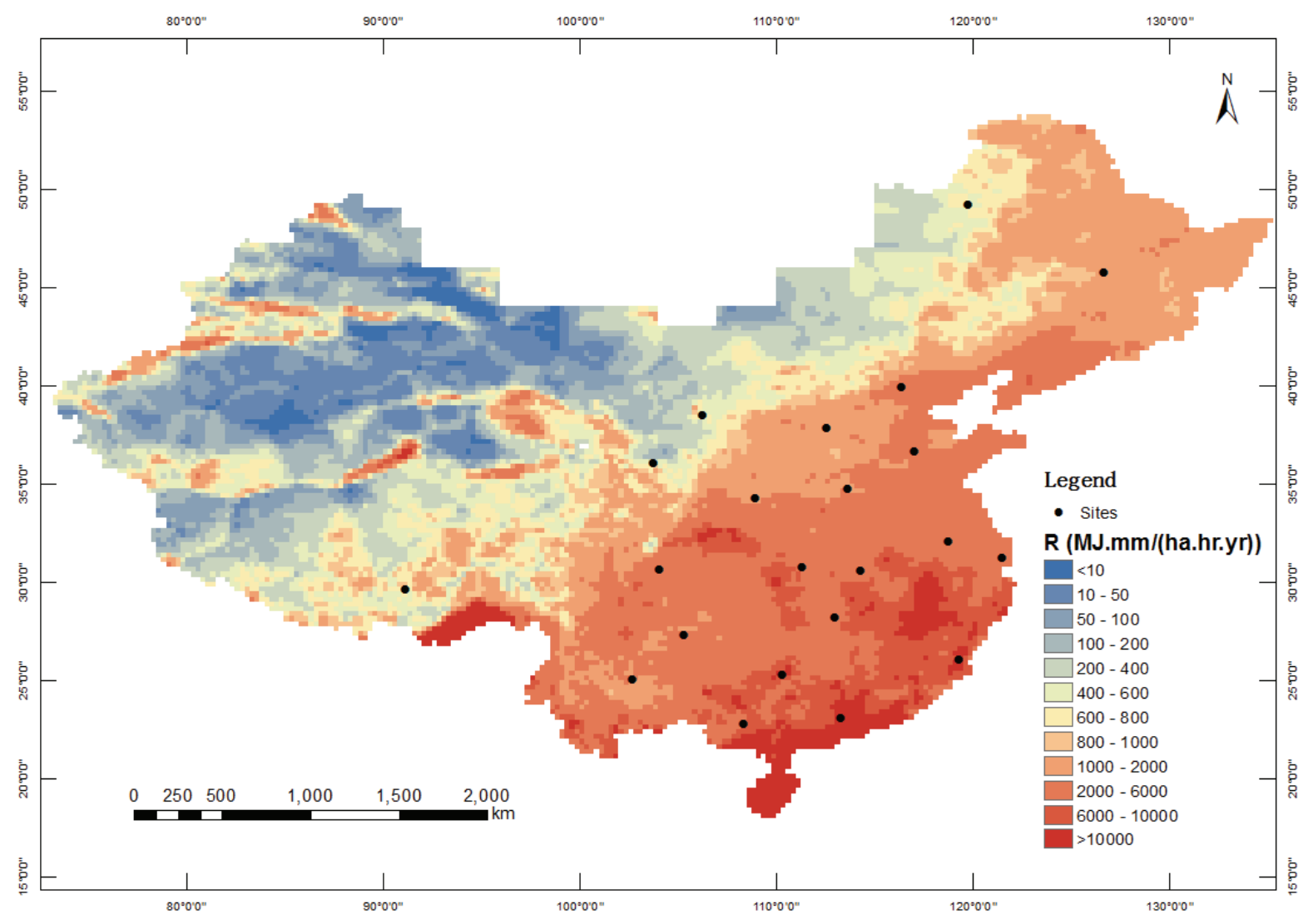

Figure 10. Spatial distribution of the predicted $\boldsymbol{R}$-factor over a 5-year period (April 2008 to March 2013) using the CMA Gridded Daily Precipitation Product. 
operational tool for estimating rainfall erosivity would benefit from further investigations into how parameter values of the model vary spatially in diverse regions of the world.

\section{ACKNOWLEDGEMENTS}

The authors thank the three anonymous reviewers for their constructive comments. We would also like to thank the Associate Editor, whose comments and edits markedly improved the quality and presentation of the manuscript.

\section{REFERENCES}

Angulo-Martínez, K., \& Beguería, S. (2009). Estimating rainfall erosivity from daily precipitation records: A comparison among methods using data from the Ebro basin (NE Spain). J. Hydrol., 379(1-2), 111-121. http://dx.doi.org/10.1016/j.jhydrol.2009.09.051.

Arnoldus, J. M. J. (1977). Methodology used to determine the maximum potential average annual soil loss due to sheet and rill erosion in Morocco. FAO Soils Bull., 34, 39-51.

Duan, N. (1983). Smearing estimate: A nonparametric retransformation method. J. American Stat. Assoc., 78(383), 605-610. http://dx.doi.org/10.1080/01621459.1983.10478017.

Ferguson, R. I. (1986). River loads underestimated by rating curves. Water Resources Res., 22(1), 74-76. http://dx.doi.org/10.1029/WR022i001p00074.

Foster, G. R., McCool, D. K., Renard, K. G., \& Moldenhauer, W. C. (1981). Conversion of the Universal Soil Loss Equation to SI metric units. J. Soil Water Cons., 36(6), 355-359.

Huang, J., Zhang, J., Zhang, Z., \& Xu, C. (2012). Spatial and temporal variations in rainfall erosivity during 1960-2005 in the Yangtze River basin. Stochastic Environ. Res. Risk Assessment, 27(2), 337-351. http://dx.doi.org/10.1007/s00477-012-0607-8.

Huang, Y., Lu, C., Zheng, T., Fu, Q., \& Xu, J. (1992). Study on rainfall erosivity index in southeastern Fujian. J. Soil Water Cons., 6, 1-5.

Jeffrey, S. J., Carter, J. O., Moodie, K. B., \& Beswick, A. R. (2001). Using spatial interpolation to construct a comprehensive archive of Australian climate data. Environ. Model. Software, 16(4), 309-330. http://dx.doi.org/10.1016/S1364-8152(01)00008-1.

Jing, K., Wang, W., \& Zheng, F. (2005). Soil Erosion and Environment in China (in Chinese). Beijing: Science Press.

King, K. W., Richardson, C. W., \& Williams, J. R. (1996). Simulation of sediment and nitrate loss on a vertisol with conservation tillage practices. Trans. ASAE, 39(6), 2139-2145. http://dx.doi.org/10.13031/2013.27717.

Liu, B. (1993). Estimation and distribution of rainfall erosive power index $(R)$ in Weibei region. J. Northwest Forestry College, 8(2), 21-29.

Liu, B., Bi, X., \& Fu, S. (2010). Beijing Soil Loss Equation (in Chinese). Beijing: Science Press.

Loague, K. M., \& Freeze, R. A. (1985). A comparison of rainfallrunoff modeling techniques on small upland catchments. Water Resources Res., 21(2), 229-248. http://dx.doi.org/10.1029/WR021i002p00229.

Lu, H., \& Yu, B. (2002). Spatial and seasonal distribution of rainfall erosivity in Australia. Australian J. Soil Res., 40(6), 887-901. http://dx.doi.org/10.1071/SR01117.

Nash, J. E., \& Sutcliffe, J. V. (1970). River flow forecasting through conceptual models: Part 1. A discussion of principles. J. Hydrol., 10(3), 282-290. http://dx.doi.org/10.1016/0022-1694(70)90255-6.

Renard, K. G., \& Freimund, J. R. (1994). Using monthly precipitation data to estimate the $R$-factor in the revised USLE. J. Hydrol., 157(1-4), 287-306. http://dx.doi.org/10.1016/00221694(94)90110-4.

Renard, K. G., Foster, G. A., Weesies, G. A., McCool, D. K., \&
Yoder, D. C. (1997). Predicting Soil Erosion by Water: A Guide to Conservation Planning with the Revised Universal Soil Loss Equation (RUSLE). Agriculture Handbook No. 703.

Washington, D.C.: USDA.

Richardson, C. W., Foster, G. R., \& Wright, D. A. (1983).

Estimation of erosion index from daily rainfall amount. Trans. ASAE, 26(1), 153-157, 160. http://dx.doi.org/10.13031/2013.33893.

Risse, L. M., Nearing, M. A., Nicks, A. D., \& Laflen, J. M. (1993). Error assessment in the Universal Soil Loss Equation. SSSA J., 57(3), 825-833. http://dx.doi.org/10.2136/sssaj1993.03615995005700030032x.

Shen, Y., Feng, M., Zhang, H., \& Gao, F. (2010). Interpolation methods of China daily precipitation data (in Chinese). J. Appl. Meteorol. Sci., 21(3), 279-286.

Sun, B., Zhao, T., \& Qi, S. (1990). Application of USLE in loessial gully hill area (in Chinese). Mem. NISWC, Acad. Sinica \& Ministry of Water Cons., 12, 50-58.

Wang, W., \& Jiao, J. (1996). Rainfall and Erosion Sediment Yield in the Loess Plateau and Sediment Transportation in the Yellow River Basin. Beijing, China: Science Press.

Wischmeier, W. H., \& Smith, D. D. (1958). Rainfall energy and its relationship to soil loss. Trans. American Geophys. Union, 39(2), 285-291.

Wischmeier, W. H., \& Smith, D. D. (1978). Predicting Rainfall Erosion Losses: A Guide to Conservation Planning. Agriculture Handbook No. 537. Washington, D.C.: USDA.

Wu, S. (1992). Research on rainfall erosivity index in Dabie Mountains, Anhui Province (in Chinese). Soil Water Cons. China, 2, 32-33.

Wu, S. (1994). Rainfall erosivity's simplified equation and temporo-spatial distribution in Dabie Mountains, Anhui Province (in Chinese). Soil Water Cons. China, 4, 12-13.

Xin, Z., Yu, X., Li, Q., \& Lu, X. (2011). Spatiotemporal variation in rainfall erosivity on the Chinese loess plateau during the period 1956-2008. Regional Environ. Change, 11(1), 149-159. $\mathrm{http} / / / \mathrm{dx}$.doi.org/10.1007/s10113-010-0127-3.

$\mathrm{Yu}$, B. (1998). Rainfall erosivity and its estimation for Australia's tropics. Australian J. Soil Res., 36(1), 143-165. http://dx.doi.org/10.1071/S97025.

$\mathrm{Yu}, \mathrm{B}$. (1999). A comparison of the $R$-factor in the Universal Soil Loss Equation and Revised Universal Soil Loss Equation. Trans. ASAE, 42(6), 1615-1620. http://dx.doi.org/10.13031/2013.13327.

Yu, B. (2003). Precipitation and erosion. In B. A. Stewart, \& T. Howell (Eds.), Encyclopaedia of Water Sciences (pp. 214-217). New York, N.Y.: Marcel Dekker.

Yu, B., \& Rosewell, C. J. (1996a). A robust estimator of the $R$ factor for the Universal Soil Loss Equation. Trans. ASAE, 39(2), 559-561. http://dx.doi.org/10.13031/2013.27535.

Yu, B., \& Rosewell, C. J. (1996b). An assessment of a daily rainfall erosivity model for New South Wales. Australian. J. Soil Res., 34(1), 139-152. http://dx.doi.org/10.1071/SR9960139.

Yu, B., Hashim, G. M., \& Eusof, Z. (2001). Estimating the $R$-factor using limited rainfall data: A case study from peninsular Malaysia. J. Soil Water Cons., 56(2), 101-105.

Zhang, W., Xie, Y., \& Liu, B. (2002). Rainfall erosivity estimation using daily rainfall amount (in Chinese). Sci. Geogr. Sinica, 22, 705-711.

Zhang, W., Xie, Y., \& Liu, B. (2003). Spatial distribution of rainfall erosivity in China (in Chinese). J. Mountain Res., 21, 33-40.

Zhang, X., Xu, J., Deng, Y., \& Gao, D. (1992). A study on the soil loss equation in Heilongjiang Province (in Chinese). Bull. Soil Water Cons., 12, 1-9, 18.

Zhou, F., Chen, M., Lin, F., Huang, Y., \& Lu, C. (1995). Rainfall erosivity index $(R)$ in Fujian Province (in Chinese). J. Soil Water Cons., 9(1), 13-18. 